\title{
Hiperurisemia dan sindroma koroner akut
}

\author{
Frans Wantania \\ Reginald L. Lefrandt
}

\author{
Bagian/SMF Ilmu Penyakit Dalam Divisi Kardiologi \\ Fakultas Kedokteran Universitas Sam Ratulangi Manado \\ Email: wantaniaerwinfrans@yahoo.com
}

\begin{abstract}
Recent studies show that hyperuricaemia plays an important role in endothelial dysfunction results in atherosclerotic plaque and myocardial infarction. Hyperuricemia can induce platelet aggregation in the vessel results in cardiovascular events. Meanwhile, inflammation plays a pivotal role in the development of atherosclerotic procces. Moreover, hyperuricemia produces reactive oxygen species that stimulate lipid peroxidation which could disrupt the biological membrane structure, therefore, triggers atherosclerotic plaque rupture and the occurence of acute coronary syndrome.
\end{abstract}

Keywords: hyperuricemia, acute coronary syndrome

\begin{abstract}
Abstrak: Beberapa penelitian telah menunjukkan adanya peran signifikan hiperurisemia terhadap terjadinya disfungsi endotel vaskuler yang akan menyebabkan pembentukan plak ateroslerosis. Hubungan antara peningkatan kadar asam urat dengan aterosklerosis adalah disfungsi endotel dan proses inflamasi. Hiperurisemia menyebabkan terbentuknya agregasi platelet pada pembuluh darah, yang akhirnya mencetus penyakit kardiovaskuler. Bahkan, hiperurisemia menyediakan terbentuknya radikal bebas, reactive oxygen species (ROS) yang menginduksi peroksidasi lipid yang dapat menganggu struktur dan kekentalan membran biologik, sehingga memicu rupturnya plak dan terjadi sindroma koroner akut.
\end{abstract}

Kata kunci: hiperurisemia, sindroma koroner akut

Penyakit jantung koroner (PJK) merupakan penyebab kematian tersering, dimana sekitar 7 juta orang meninggal setiap tahunnya akibat PJK, yaitu sekitar 12,8\% dari seluruh kematian. ${ }^{1}$ Insiden sindroma koroner akut (SKA) dengan ST-segment elevation myocardial infarction (STEMI) dan non ST-segment elevation myocardial infarction (NSTEMI) bervariasi di setiap negara. ${ }^{2-3}$ Di Amerika Serikat, dari 1.57 juta pasien yang masuk rumah sakit dengan SKA, 330.000 kasus diantaranya dengan STEMI, dan 1.24 juta kasus dengan NSTEMI. ${ }^{1}$

Hubungan independen antara kadar asam urat dan angka kematian setelah penentuan variabel risiko penyakit kardiovaskulerlainnya menunjukkan bahwa kadar asam urat dapat memberikan nilai prognostik pada pasien, dimana peningkatan nilai asam urat berhubungan dengan faktor risiko SKA. Peranan kadar asam urat sebagai faktor prognostik pada pasien dengan IMA masih kontrovesial. Pada seluruh spektrum SKA, adanya peningkatan kadar asam urat berhubungan independen dengan semua penyebab kematian pada follow up jangka menengah, dimana untuk setiap kenaikan $1 \mathrm{mg} / \mathrm{dL}$ asam urat, perkiraan risiko mortalitas 1 tahun meningkat sebesar $26 \%$. $^{4}$

Arti penting dari hubungan ini masih belum diketahui. Masih terdapat kontroversi mengenai pentingnya peran hiperurisemia dalam penyakit kardiovaskular: apakah hanya sebagai penanda, 
faktor risiko, atau juga merupakan faktor prognostik. Berikut ini akan dibahas mengenai peranan asam urat dalam kejadian sindrom koroner akut.

\section{Sindrom koroner akut}

Sindroma koroner akut (SKA) adalah gabungan gejala klinik yang menandakan iskemia miokard akut, terdiri dari angina pektoris tidak stabil (unstable angina pectoris $=$ UAP), STEMI, dan NSTEMI. ${ }^{3}$ Secara tradisional, nyeri dada pada SKA dapat bermanifestasi mulai dari: nyeri dada lebih dari 20 menit saat istirahat,serangan angina baru - de novo (kelas II/III Classification of Canadian Cardiovascular Society), recent destabilization dengan angina stabil sebelumnya dikarakteristik oleh angina kelas III Canadian Cardiovascular Society (crescendo angina) atau angina post MI. ${ }^{5}$ Presentasi nyeri dada khas pada SKA yaitu perasaan tertekan di daerah retrosternal atau terasa berat (angina) yang menjalar sampai ke lengan kiri, leher, atau rahang, dapat terjadi hilang timbul atau menetap. Keluhan ini dapat juga bersamaan dengan diaforesis, nausea, nyeri perut, dispnu dan pingsan. ${ }^{1}$

Kriteria diagnosis infark miokard berdasarkan WHO tahun 2000 yaitu didapatkan 2 dari 3 gejala, yaitu nyeri dada khas infark yang berlangsung selama lebih dari 20 menit yang tidak dipengaruhi oleh istirahat maupun oleh pemberian nitrat, evolusi EKG khas infark, dan peningkatan serum penanda jantung. .,7 $^{\circ}$

\section{Inflamasi dan sindroma koroner akut}

Penelitian selama beberapa dekade terakhir ini menunjukkan bahwa inflamasi merupakan kunci utama dalam terjadinya PJK dan manifestasi lain dari aterosklerosis. ${ }^{8}$ Berbagai faktor ikut berperan dalam patogenesis aterosklerosis meliputi disfungsi endotel, dislipidemia, faktor inflamasi dan imunologik, ruptur plak, dan merokok. Pada proses aterosklerosis, terdapat kunci utama yang terlibat dalam perkembangan disfungsi endotel, yaitu oksidasi low-density lipoprotein (oxLDL) dan aktivasi berbagai tipe sel dan agen chemoattractant. ${ }^{9}$ Sel-sel imun mendominasi dalam lesi awal aterosklerosis, molekul efektornya dapat mempercepat perkembangan lesi aterosklerosis, dan aktivasi inflamasi dapat menyebabkan terjadinya SKA. $^{10}$

Beberapa penelitian mengenai mekanisme trombosis koroner dengan lebih menfokuskan pada ruptur plaks sebagai penyebab SKA yang paling sering dan dapat berakibat fatal. Hubungan antara penipisan fibrous cap dan ruptur plak yang fatal menuju pada kesimpulan bahwa kelainan pada metabolisme kolagen berperan dalam kehilangan protein matriks ekstrasel yang berperan penting dalam mempertahankan kekuatan fibrous cap. ${ }^{11}$

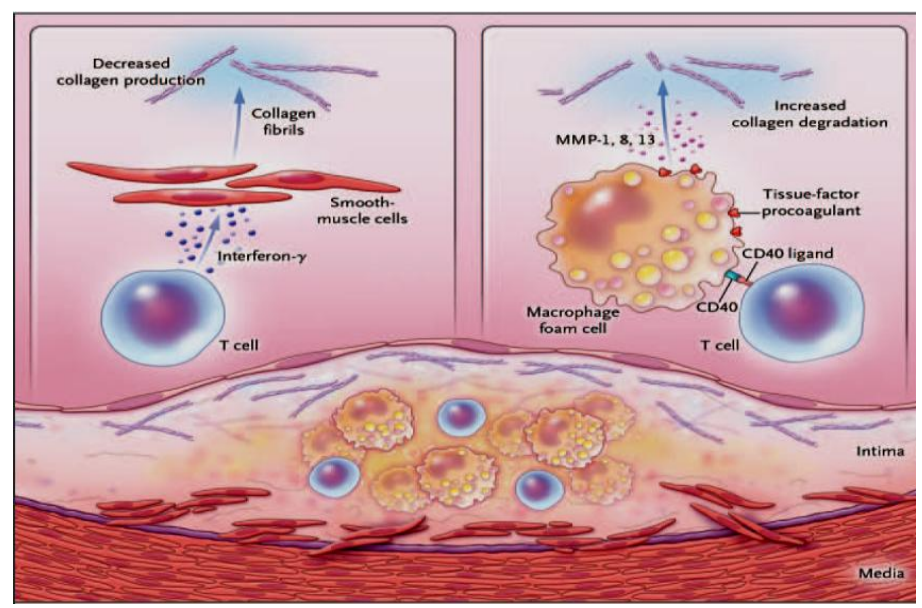

Gambar 1 Proses inflamasi yang mencetus terjadinya ruptur dan trombosis arteri koroner. Sumber: Libby P, 2013. ${ }^{11}$ 


\section{Hiperurisemia dan disfungsi endotel}

Endotel vaskuler memiliki fungsi sebagai biological barrier terhadap aliran sel darah dan berbagai larutan yang berasal dari sel-sel otot polos pembuluh darah atau vascular smooth muscle cells (VSMC). ${ }^{12}$ Endotel meregulasi permeabilitas dan tonus otot vaskuler dan menjaga keseimbangan antara koagulasi dan fibrinolisis. Endotel juga diketahui meregulasi pelepasan berbagai mediator pembuluh darah seperti nitric oxide (NO), faktor Von Willebrand, endotelin-1 (ET-1), angiotensin II (Ang-II), molekul-molekul adhesi dan sitokin. ${ }^{13}$ Nitric oxide ialah mediator utama yang dihasilkan endotel yang dibentuk dari $L$ arginine dengan bantuan enzim endothelial nitric oxide synthase (eNOS). Nitric oxide memiliki sifat vasodilator, anti platelet, anti proliferasi, anti-aterogenik, anti inflamasi, dan dapat menurunkan permeabilitas vaskuler. $^{14,15}$

Disfungsi endotel vaskuler atau vascular endothel dysfunction (VED) merupakan suatu keadaan patologik yang kronik dimana pembentukan dan bioavailabilitas NO menurun dan menyebabkan berkurangnya ekspresi dan aktivasi eNOS. ${ }^{15}$ Disfungsi endotel disebabkan oleh adanya produksi reactive oxygen species (ROS) dan eNOS tidak berpasangan (uncoupled) menyebabkan turunnya produksi NO. Stres oksidatif berperan penting dalam patogenesis VED. Selanjutnya, terjadi peningkatan ekspresi $P$-selectin, vascular cell adhesion molecule-1 (VCAM-1), dan monocyte chemotactic protein-1 (MCP-1) yang menghasilkan perlekatan monosit dan limfosit yang bersirkulasi, dan menginduksi apoptosis kematian sel, yang kemudian bersama dengan makrofag dan trombosit, memulai terjadinya migrasi dan proliferasi sel otot polos (smooth muscle cells, SMCs). ${ }^{9}$

Disfungsi endotel vaskuler meningkatkan asymmetric dimethyl arginine (ADMA), suatu inhibitor endogen eNOS yang menurunkan pembentukan dan bioavailabilitas NO. Asymmetric dimethyl arginine dapat diinaktivasi oleh dimethyl arginine dimethylaminohydrolase (DDAH). Penurunan aktivitas DDAH menyebabkan akumulasi ADMA, yang mungkin sebagai kunci utama terjadinya VED, dimana dapat menghambat eNOS dan mencetuskan terlepasnya mediator proaterogenik. ${ }^{14}$

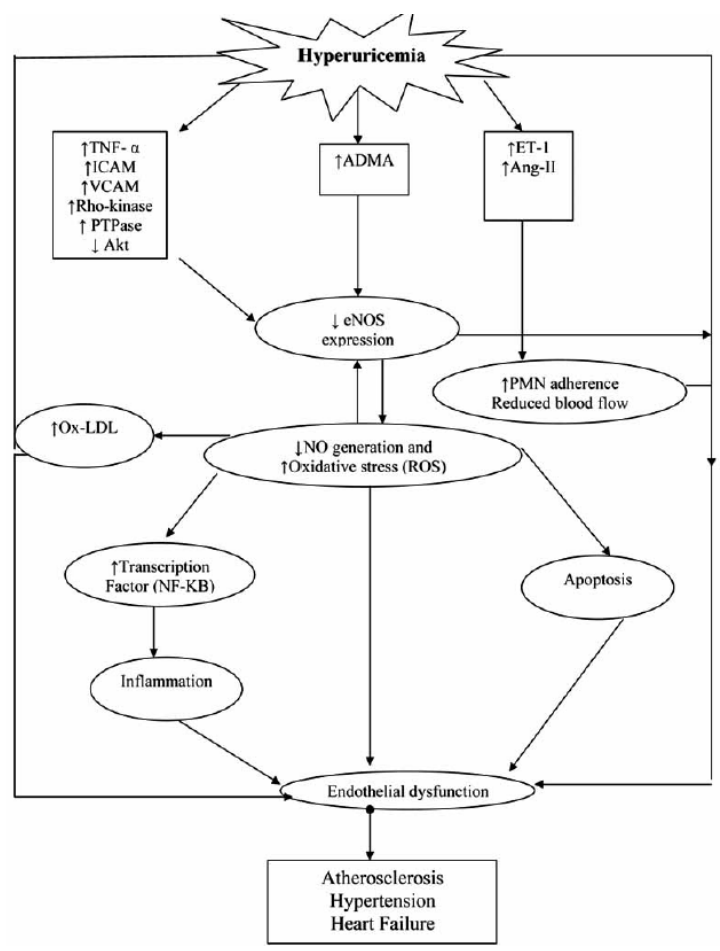

Gambar 2. Mekanisme patologis yang terlibat dalam hiperurisemia-menginduksi disfungsi endotel vaskuler. Sumber: Balakumar $\mathrm{P}$ et al, 2009. ${ }^{14}$

Peningkatan asam urat meningkatkan mediator proinflamasi pada sel otot polosvaskular (VSMC). Hiperurisemia juga dapat menyebabkan oksigenasi LDL dan mencetuskan terbentuknya peroksidasi lipid, yang dapat menyebabkan penebalan intima yang akhirnya mencetuskan terbentuknya aterosklerosis. ${ }^{11}$

Berbagai penelitian mencoba menunjukkan bahwa hiperurisemia dapat mempercepat terjadinya VED. Hiperurisemia dapat menurunkan terbentuknya NO sepanjang inaktivasi eNOS. Hiperurisemia juga dapat menghasilkan ROS yang berlebihan sepanjang aktivasi NADPH oksidase dan XO. Dengan terbentuknya ROS, berbagai mediator 
vasokonstriksi juga ikut terbentuk, yang mungkin dapat memengaruhi fungsi endotel. Nilai $C$-reactive protein (CRP) meningkat pada keadaan VED yang dicetuskan oleh hiperurisemia. Peningkatan nilai CRP mengganggu pembentukan dan bioavailabilitas NO melalui penurunan pengaturan ekspresi eNOS. Ekspresi berlebihan mediator-mediator inflamasi seperti MCP-1, penurunan pengaturan protein kinase (Akt) dan peningkatan pengaturan protein tyrosine phosphatase (PTPase) mungkin berperan penting dalam patogenesis VED. Peningkatan nilai asam urat menyebabkan peningkatan bermakna tumor necrosis factor (TNF-alpha). ${ }^{15}$

Kenaikan nilai asam urat mungkin berpengaruh terhadap terbentuknya ROS dan secara tidak langsung menyebabkan disfungsi endotel. Walaupun demikian hiperurisemia juga dapat secara langsung menyebabkan kerusakan vaskular. Pada konsentrasi tinggi, asam urat menyebabkan proliferasi sel otot polos, agregasi trombosit, apoptosis sel, dan inflamasi lokal. ${ }^{16,17}$

Beberapa penelitian telah menunjukkan adanya peran signifikan hiperurisemia terhadap terjadinya VED yang akan menyebabkan pembentukan plak ateroslerosis dan pada akhirnya menyebabkan terjadinya IMA dibandingkan dengan individu yang kadar asam uratnya normal. ${ }^{15,18}$

\section{Hiperurisemia dan infark miokard}

Hubungan antara peningkatan kadar asam urat dengan aterosklerosis ialah disfungsi endotel dan proses inflamasi. ${ }^{14,15}$ Hiperurisemia menyebabkan terbentuknya agregasi platelet pada pembuluh darah, yang akhirnya mencetus penyakit kardiovaskuler. Nilai trigliserida, apolipoprotein $\mathrm{B}$ dan apolipoprotein $\mathrm{E}$ meningkat dan nilai high density lipoprotein (HDL) menurun pada hiperurisemia menyebabkan terbentuknya aterosklerosis. Bahkan, hiperurisemia menyediakan terbentuknya radikal bebas, yang merangsang peroksidasi lipid sehingga meningkatkan ketebalan intima. Selanjutnya, LDL yang teroksidasi berpengaruh dalam penghambatan transkripsi dan ekspresi eNOS. Reactive oxygen species menginduksi peroksidasi lipid yang dapat menganggu struktur dan kekentalan membran biologi, sehingga akhirnya memengaruhi fungsi vaskuler. $^{19,20}$

Hiperurisemia menginduksi terjadinya arteriolopathy pada pembuluh darah preglomerular, yang mengganggu respon autoregulator dari arteriol afferen, menyebabkan hipertensi glomerular. ${ }^{11}$ Hiperurisemia meningkatkan nilai renin plasma dan menyebabkan terbentuknya Ang II, selanjutnya terjadi aktivasi makrofag dan peningkatan produksi sitokin sehingga terjadi inflamasi serta peningkatan ROS dan peroksidase lemak, yang mencetuskan terjadinya aterosklerosis. ${ }^{15}$

Pada percepatan proses aterosklerosis, dengan peningkatan stres oksidatif dan ROS yang mendasarinya, juga bersamaan dengan eNOS endotel yang tidak berpasangan dan menurunnya produksi antioksidan lokal yang terbentuk secara alami menyebabkan terbentuk plak yang rapuh, intima pembuluh darah menjadi suasana asam, hilangnya pengaruh antioksidan lokal, dan terjadi disfungsi endotel. Hal ini menunjukkan bahwa peningkatan asam urat yang terjadi ialah sebagai respon antioksidan terhadap stres oksidatif pada pasien dengan faktor risiko tradisional dan PJK. Aktivasi xanthine oxidase (XO) akan meningkatkan stres oksidatif lebih jauh, dan dengan kapasitas asam urat serum sebagai antioksidan yang kurang, stres oksidatif menyebabkan cedera vaskular. $^{21,22}$

Penelitian Multiple Risk Factors Intervention Trial (MRFIT) mendapatkan bahwa hiperurisemia merupakan faktor risiko independen terhadap IMA. $^{23}$ Penelitian Apolipoprotein Mortality Risk Study (AMORIS) mendapatkan adanya peningkatan kadar asam urat serum berhubungan dengan peningkatan insiden IMA pada pasien dewasa tanpa adanya riwayat penyakit kardiovaskuler sebelumnya. $^{24}$ Penelitian lain secara tinjauan 
sistematik dan meta-analisis, menunjukkan bahwa hiperurisemia secara marginal dapat meningkatkan kejadian PJK dan bersifat independen dengan faktor-faktor risiko tradisional lainnya. ${ }^{25}$

Asam urat juga dapat dipakai untuk mengindentikasi pasien dalam kelompok derajat berat ringannya SKA. Penelitian oleh Timoteo et al. ${ }^{4}$ tahun 2013, menunjukkan bahwa menambahkan nilai asam urat serum dengan GRACE risk score mungkin dapat lebih baik untuk mengidentifikasi pasien dalam kelompok risiko rendah. Pada pasien dengan keseluruhan spektrum SKA, peningkatan nilai asam urat merupakan faktor independen terkait dengan semua penyebab kematian lain pada follow-up pasien jangka pendek dan dengan menambahkan nilai asam urat memiliki nilai prediktif diatas GRACE risk score dimana untuk setiap peningkatan asam urat $1 \mathrm{mg} / \mathrm{dL}$, risiko mortalitas 1 tahun meningkat $26 \%$.

Pengelompokan risiko pasien SKA menjadi kelompok dengan risiko tinggi, sedang, atau risiko rendah, berdasarkan berbagai faktor penting menurut rekomendasi dari ACC/AHA yang terkini, karena hal ini akan memiliki implikasi klinis dalam segi penanganan yang berbeda berdasarkan derajat beratnya risiko. ${ }^{25}$ Oleh karena itu kadar asam urat dapat dipertimbangkan sebagai faktor risiko independen dalam kejadian SKA. Nilai prognostik asam urat dalam prediksi mortalitas hanya dapat menilai angka kematian jangka pendek, sedangkan untuk menilai angka kematian jangka panjang belum cukup banyak data penelitian yang tersedia.

\section{Simpulan}

Sindroma koroner akut adalah gabungan gejala klinik yang menandakan iskemia miokard akut, terdiri dari UAP, STEMI, dan NSTEMI. Hubungan asam urat dan risiko kardiovaskuler telah dinyatakan pada berbagai penelitian epidemiologi dan dilaporkan melalui disfungsi endotel dan proses inflamasi. Hiperurisemia merupakan faktor risiko independen terhadap IMA. Adanya peningkatan kadar asam urat serum pada pasien dengan PJK dapat dijadikan salah satu faktor risiko penting terhadap perkembangan PJK disamping faktor-faktor tradisional lainnya.

Walaupun peran asam urat sebagai faktor prognostik pada pasien IMA masih kontroversi, tetapi beberapa penelitian menunjukkan bahwa asam urat memiliki nilai prognostik terhadap mortalitas dalam jangka pendek, sehingga diperlukan perhatian khusus dan penanganan yang lebih agresif pada pasien hiperurisemia dengan PJK.

\section{DAFTAR PUSTAKA}

1. Jneid H, Anderson JL, Wright RS. Adams CD, Bridges CR, Casey DE, et al. 2012 ACCF/AHA Focused Update of the guideline for the mnagement of patients with unstable angina/non-STelevation myocardial infarction (Updating the 2007 guideline and replacing the 2011 Focused Update): A report of the American College of Cardiology Foundation/ American Heart Association Task Force on practice guidelines. Circulation. 2012;126:875-910.

2. Steg G, James K, Atar D, Badano LP, Lundqvist CB, Di Mario C, et al. ESC guidelines for the management of acute myocardial infarction in patients presenting with ST-segment elevation. The Task Force on the management of ST-segment elevation acute myocardial infarction of ther European Society of Cardiology (ESC). Eur Heart J. 2012:33:2569-619.

3. Roger VL, Go AS, Lloyd-Jones DM, Benjamin EJ, Berry JD, Borden WB, et al. Executive summary: Heart disease and stroke statistics--2012 update: A report from the American Heart Association. Circulation. 2012;125:188-97.

4. Timoteo A, Lousinha A, Labandeiro J, Miranda F, Papoila AL, Oliveira JA, et al. Serum uric acid: a forgotten prognostic marker in acute coronary syndromes? Eur Heart J Acute Cardiovasc Care. 2013;2(1):44-52.

5. Hamm C, Bassand JP, Agewall S, Bax J, 
Boersma E, Bueno $\mathbf{H}$, et al. ESC Guidelines for the management of acute coronary syndromes in patients presenting without persistent STsegment elevation. The Task Force for the management of acute coronary syndromes (ACS) in patients presenting without persistent ST-segment elevation of the European Society of Cardiology (ESC). Eur Heart J. 2011;32:2999-3054.

6. Kumar A, Cannon C. Acute Coronary Syndromes: Diagnosis and Management, Part I. Mayo Clin Proc 2009;84(10):917-938.

7. Kleinschmidt $\mathbf{K}$. Epidemiology and patophysiology of acute coronary syndrome. Adv Stud Med 2006;6(6B):S477-S482.

8. Crea F, Liuzzo G. Pathogenesis of Acute Coronary Syndromes. Journal of the American College of Cardiology 2013;61: 1-11.

9. Tousoulis D, Kampoli AM, Papageorgiou $\mathbf{N}$, Androulakis $\mathrm{E}$, Antoniades $\mathrm{C}$, Toutouzas K, et al. Patophysiology of atherosklerosis: the role of inflammation. Curr Pharm Des 2011;17(37): 4089-110.

10. Hanson G. Inflammation, atherosklerosis, and coronary artery disease. $\mathrm{N}$ Engl $\mathrm{J}$ Med. 2005;352(16):1685-95.

11. Libby $\mathbf{P}$. Mechanism of acute coronary syndromes and their impilcations for therapy. N Engl J Med. 2013;368(21):2004-13.

12. Iliesiu A, Campeanu A, Dusceac D. Serum uric acid and cardiovascular disease. Maedica. 2010;5(3):186-92..

13. Terkeltaub $R$. Update on gout: new therapeutic strategies and options. Nat Rev Rheumatol. 2010;6(1):30-8.

14. Balakumar P, Sharma R, Kalia, Singh M. Hyperuricemia: Is it a Risk Factor for Vascular Endothelial Dysfunction and Associated Cardiovascular Disorders?. Curr Hypertens Rev. 2009; 5:1-6.

15. Hayden M, Tyagi S. Uric acid: A new look at an old risk marker for cardiovascular disease, metabolic syndrome, and type
2 diabetes mellitus: The urate redox shuttle. Nutr Metab. 2004;1:10.

16. Hozawa A, Folsom AR, Ibrahim H, Javier NF, Rosamond WD, Shahar E. Serum uric acid and risk of ischemic stroke: the ARIC Study. Atherosclerosis, 2006;187(2):401-7.

17. Bos M, Koudstaal P, Hofman A, Witteman J, Breteler M. Uric acid is a risk factor myocardial infarction and stroke: the Roterdam study. Stroke 2006;37:1503-7.

18. Feig D, Kang DH, Johnson R. Uric acid and cardiovascular risk. N Engl J Med 2008;359:1811-21.

19. Baker JF, Schumacher HR, Krishnan E. Serum uric acid level and risk for peripheral arterial disease: analysis of data from the multiple risk factor intervention trial. Angiology. 2007; 58(4):450-7.

20. Bae JH, Hyun DW, Kwon TG, Yoon HJ, Lerman A, Rihal CS. Serum uric acid is associated with cardiovascular events in patients with coronary artery disease. Korean Circ J. 2007;37:161-6.

21. Waring WS, Webb DJ, Maxwell SRJ. Uric acid as a risk factor for cardiovascular disease. Q J Med. 2000; 93:707-13.

22. Homayounfar S, Ansari M, Kashani K. Evaluation of independent prognostic importance of hyperuricemia in hospital death after acute myocardial infarction. Saudi Med J. 2007;28(5):759-61.

23. Trkulja V, Car S. On-admission serum uric acid predicts outcomes after acute myocardial infarction: systematic review and metaanalysis of prognostic studies. Croat Med J. 2012;53:162-72.

24. Ndrepepa G, Braun S, Haase H-U, Schulz S, Ranftl S, Hadamitzky M, et al. Prognostic value of uric acid in patients with acute coronary syndromes. Am J Cardiol 2012;109:1260-5.

25. Ho WJ, Tsai WP, Yu KH, Tsay PK, Wang CL, Hsu TS, et al. Association between endothelial dysfunction and hyperuricemia. Rheumatol (Oxford). 2010;49:1929-34. 